\title{
Microwave-assisted three-component domino reaction: Synthesis of indolodiazepinotriazoles
}

\author{
Rajesh K. Arigela ${ }^{1}$, Sudhir K. Sharma ${ }^{1}$, Brijesh Kumar ${ }^{2}$ and Bijoy Kundu ${ }^{* 1,2, \S}$
}

\section{Full Research Paper}

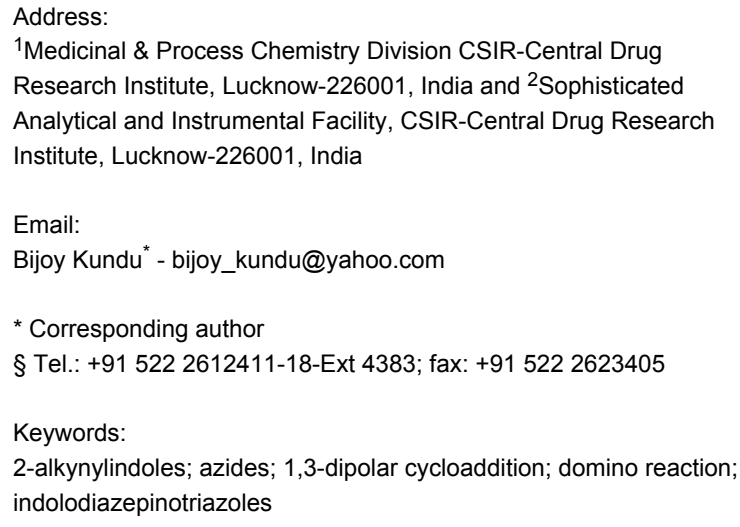

\author{
Beilstein J. Org. Chem. 2013, 9, 401-405. \\ doi:10.3762/bjoc.9.41 \\ Received: 27 November 2012 \\ Accepted: 23 January 2013 \\ Published: 19 February 2013 \\ Associate Editor: J. P. Wolfe \\ (C) 2013 Arigela et al; licensee Beilstein-Institut. \\ License and terms: see end of document.
}

\begin{abstract}
A microwave-assisted three-component protocol involving $N-1$ alkylation of 2-alkynylindoles with epichlorohydrin, ring opening of the epoxide with sodium azide, and an intramolecular Huisgen azide-internal alkyne 1,3-dipolar cycloaddition domino sequence has been described. The efficacy of the methodology has been demonstrated by treating various 2-alkynylindoles (aromatic/aliphatic) with epichlorohydrin and sodium azide furnishing annulated tetracyclic indolodiazepinotriazoles in satisfactory yields.
\end{abstract}

\section{Introduction}

The intermolecular Huisgen azide-alkyne 1,3-dipolar cycloaddition reaction [1-6] for the synthesis of 1,2,3-triazoles in both aqueous [7-10] and organic solvents under either metalcatalyzed [11-13] or metal-free conditions [14-16] has received increasing attention in drug discovery processes $[17,18]$. The ease of reaction in the intermolecular format has been successfully demonstrated by using both organic/inorganic azides as well as alkynes/diynes [19-21]. In contrast to its employment in an intermolecular format, intramolecular azide-alkyne 1,3dipolar cycloaddition reactions have been also applied by us and others with the view to synthesize triazole-annulated poly- heterocycles. Although these cyclizations have been successfully carried out in either one-pot [22-24] or multistep format [25-28], reports involving their application in a three-component domino format are scarce [29,30]. In our laboratory, we had been employing functionalized indoles for the synthesis of annulated indole-based polyheterocycles either in a multicomponent or in a one-pot format [31-35]. In this continuation, we next directed our efforts to the development of a three-component domino strategy for the synthesis of indole-based polyheterocycles by incorporating the intramolecular azide-alkyne 1,3dipolar cycloaddition reaction as one of the domino steps. Here 
we propose a strategy where $N$-1 of 2-alkynylindole [36,37] can be first functionalized with epoxide by reacting 2-alkynylindole with epichlorohydrin. This can then be followed by ring opening of the oxirane by azide to furnish a bis-functionalized indole intermediate having azide and alkyne groups in close proximity. Such an intermediate may then undergo annulation following an intramolecular 1,3-dipolar cycloaddition pathway and in turn lead to the sequential formation of 7- or 5 -membered diazepine and triazole rings in a single step. In this communication, we report a versatile microwave-assisted three component domino reaction to furnish annulated tetracyclic indolodiazepinotriazoles in good yields.

\section{Results and Discussion}

We commenced our studies with the development of a one-pot three-component strategy involving the condensation of the 2-(4-methylphenylethynyl)-1H-indole (1a) with epichlorohydrin (2) and sodium azide (3, Scheme 1, Table 1). Initially, a mixture of 1a, 2 and $\mathbf{3}$ was allowed to react both in the absence and presence of $\mathrm{Cs}_{2} \mathrm{CO}_{3}$ in toluene at $\mathrm{rt}$. The reactants under both the conditions remained unchanged even after prolonged stirring for $15 \mathrm{~h}$ (Table 1, entries 1-3) and at higher temperature $\left(110^{\circ} \mathrm{C}\right)$.

However, a change in the nature of solvent from toluene to $\mathrm{CH}_{3} \mathrm{CN}$, DMF or DMSO produced a dramatic effect on the outcome of the reaction, resulting in the formation of products comprising intermediates (4a and/or 5a) and/or indole-based polyheterocycle indolodiazepinotriazole 6a. Use of the polar solvent $\mathrm{CH}_{3} \mathrm{CN}$ at $90{ }^{\circ} \mathrm{C}$ for $15 \mathrm{~h}$ furnished a single product in $65 \%$ isolated yield, which was characterized as 2-[2-(4-methyl-
Table 1: Optimization of reaction conditions for the synthesis of $6 \mathbf{a}$ in a three-component domino format.

\begin{tabular}{|c|c|c|c|c|c|}
\hline Entry & Base & Solvent & Temp $\left({ }^{\circ} \mathrm{C}\right)$ & Time & $\begin{array}{l}\text { Yield (\%) } \\
\text { of } 4 a / 5 a / 6 a\end{array}$ \\
\hline 1 & - & toluene & rt & $15 \mathrm{~h}$ & $N R$ \\
\hline 2 & $\mathrm{Cs}_{2} \mathrm{CO}_{3}$ & toluene & $\mathrm{rt}$ & $15 \mathrm{~h}$ & NR \\
\hline 3 & $\mathrm{Cs}_{2} \mathrm{CO}_{3}$ & toluene & 110 & $15 \mathrm{~h}$ & NR \\
\hline 4 & $\mathrm{Cs}_{2} \mathrm{CO}_{3}$ & $\mathrm{CH}_{3} \mathrm{CN}$ & 90 & $15 \mathrm{~h}$ & $65 /-1-$ \\
\hline 5 & $\mathrm{Cs}_{2} \mathrm{CO}_{3}$ & DMF & $\mathrm{rt}$ & $15 \mathrm{~h}$ & NR \\
\hline 6 & $\mathrm{Cs}_{2} \mathrm{CO}_{3}$ & DMF & 120 & $1 \mathrm{~h}$ & $77 /-1-$ \\
\hline 7 & $\mathrm{Cs}_{2} \mathrm{CO}_{3}$ & DMF & 120 & $4 \mathrm{~h}$ & $40 / 30 /-$ \\
\hline 8 & $\mathrm{Cs}_{2} \mathrm{CO}_{3}$ & DMF & 120 & $15 \mathrm{~h}$ & $-/ 15 / 50$ \\
\hline 9 & $\mathrm{Cs}_{2} \mathrm{CO}_{3}$ & DMF & 120 & $18 \mathrm{~h}$ & $-1-160$ \\
\hline 10 & $\mathrm{Cs}_{2} \mathrm{CO}_{3}$ & DMSO & 120 & $1 \mathrm{~h}$ & $82 /-1-$ \\
\hline 11 & $\mathrm{Cs}_{2} \mathrm{CO}_{3}$ & DMSO & 120 & $4 \mathrm{~h}$ & $42 / 40 /-$ \\
\hline 12 & $\mathrm{Cs}_{2} \mathrm{CO}_{3}$ & DMSO & 120 & $10 \mathrm{~h}$ & $-/ 20 / 52$ \\
\hline 13 & $\mathrm{Cs}_{2} \mathrm{CO}_{3}$ & DMSO & 120 & $15 \mathrm{~h}$ & $-/-/ 64$ \\
\hline 14 & $\mathrm{Cs}_{2} \mathrm{CO}_{3}$ & DMSO & $120 \mathrm{MW}$ & $10 \mathrm{~min}$ & 80/-1- \\
\hline 15 & $\mathrm{Cs}_{2} \mathrm{CO}_{3}$ & DMSO & $120 \mathrm{MW}$ & $30 \mathrm{~min}$ & $20 / 45 / 10^{b}$ \\
\hline 16 & $\mathrm{Cs}_{2} \mathrm{CO}_{3}$ & DMSO & $120 \mathrm{MW}$ & $1 \mathrm{~h}$ & $-/ 18 / 42$ \\
\hline 17 & $\mathrm{Cs}_{2} \mathrm{CO}_{3}$ & DMSO & $120 \mathrm{MW}$ & $1.5 \mathrm{~h}$ & $-\mid-/ 71$ \\
\hline 18 & $\mathrm{Cs}_{2} \mathrm{CO}_{3}$ & DMF & $120 \mathrm{MW}$ & $1.5 \mathrm{~h}$ & $-1-164$ \\
\hline 19 & $\mathrm{Cs}_{2} \mathrm{CO}_{3}$ & $\mathrm{CH}_{3} \mathrm{CN}$ & $90 \mathrm{MW}$ & $1.5 \mathrm{~h}$ & $80 /-1-$ \\
\hline 20 & $\mathrm{Cs}_{2} \mathrm{CO}_{3}$ & $\mathrm{CH}_{3} \mathrm{OH}$ & $90 \mathrm{MW}$ & $1.5 \mathrm{~h}$ & NR \\
\hline 21 & $\mathrm{~K}_{2} \mathrm{CO}_{3}$ & DMSO & $120 \mathrm{MW}$ & $1.5 \mathrm{~h}$ & $-/ 10 / 54^{b}$ \\
\hline 22 & $\mathrm{Na}_{2} \mathrm{CO}_{3}$ & DMSO & $120 \mathrm{MW}$ & $1.5 \mathrm{~h}$ & $-/ 12 / 52^{b}$ \\
\hline 23 & $\mathrm{~K}_{3} \mathrm{PO}_{4}$ & DMSO & $120 \mathrm{MW}$ & $1.5 \mathrm{~h}$ & $-/-162$ \\
\hline 24 & $t$-BuOK & DMSO & $120 \mathrm{MW}$ & $1.5 \mathrm{~h}$ & $-/-/ 65$ \\
\hline 25 & DBU & DMSO & $120 \mathrm{MW}$ & $1.5 \mathrm{~h}$ & $-/ 15 / 48^{b}$ \\
\hline 26 & TEA & DMSO & $120 \mathrm{MW}$ & $1.5 \mathrm{~h}$ & $-/ 20 / 45^{b}$ \\
\hline
\end{tabular}

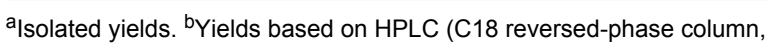
$150 \times 4.8 \mathrm{~mm}, 5 \mu \mathrm{m}) . \mathrm{NR}=$ no reaction.
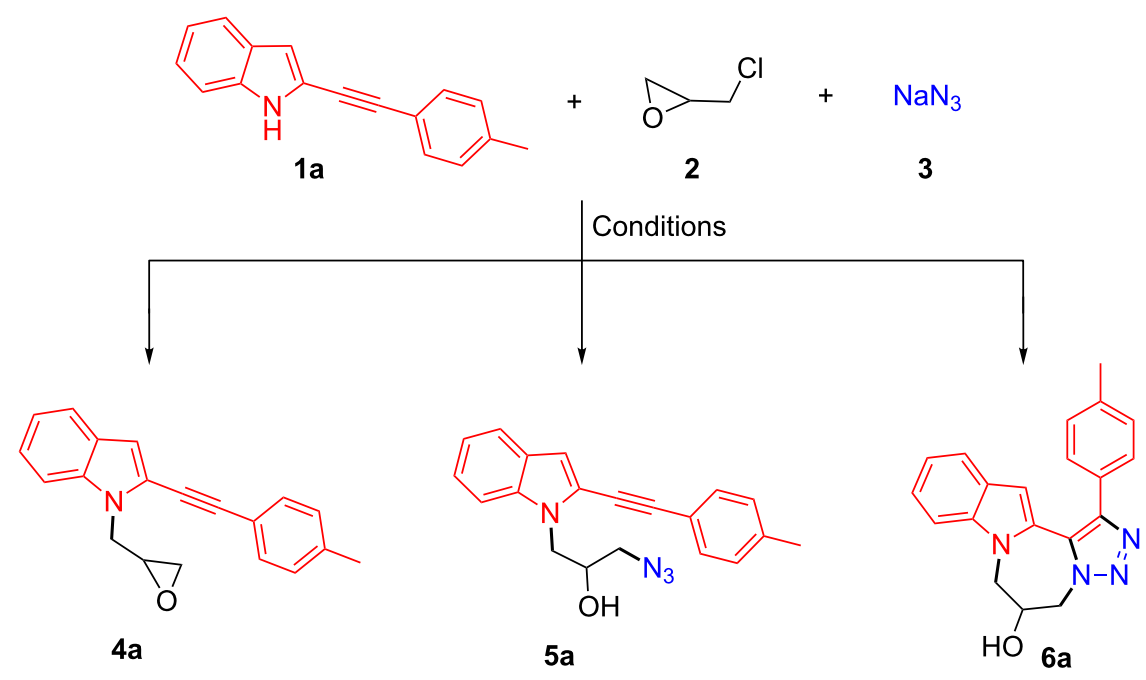
phenyl)ethynyl]-1-(oxiran-2-ylmethyl)-1 $H$-indole (4a, Table 1 , entry 4). In contrast, use of the polar aprotic solvent DMF with high dielectric constant produced both intermediates $\mathbf{4 a} / \mathbf{5 a}$ as well as the annulated product 6a. Interestingly, a significant increase in the yield of the title compound $\mathbf{6 a}$ was observed by prolonging the reaction. Carrying out the reaction in DMF at $\mathrm{rt}$ also failed to promote annulation even after $15 \mathrm{~h}$ of prolonged stirring (Table 1, entry 5). Increasing the temperature to $120^{\circ} \mathrm{C}$ furnished the intermediate $4 \mathbf{a}$ as a single product in $77 \%$ isolated yield within $1 \mathrm{~h}$ (Table 1, entry 6). Further stirring up to $4 \mathrm{~h}$ at $120^{\circ} \mathrm{C}$ led to the partial conversion of $4 \mathbf{a}$ (by ring opening of the epoxide with $\mathrm{NaN}_{3}$ ) into yet another intermediate 1-azido-3-\{2-[2-(4-methylphenyl)ethynyl]-1H-indol-1yl) propan-2-ol (5a, Table 1, entry 7) in 30\% isolated yield. Nonetheless, extending the reaction times up to $15 \mathrm{~h}$, led to the complete disappearance of $\mathbf{4 a}$ and furnished a mixture of the intermediate $\mathbf{5 a}$ in $15 \%$ isolated yield and the title compound $\mathbf{6 a}$ characterized as 1-(4-methylphenyl)-6,7-dihydro-5H-[1,2,3]triazolo[5', $\left.1^{\prime}: 3,4\right][1,4]$ diazepino[1,2-a] indol-6-ol in 50\% isolated yield (Table 1 , entry 8 ). The findings clearly suggest that the formation of indole-based annulated product $\mathbf{6 a}$ in the threecomponent domino format occurs via $\mathbf{4 a}$ and $\mathbf{5 a}$ intermediacy and requires higher temperature and prolonged stirring. This was again evident from the fact that a prolonged stirring up to $18 \mathrm{~h}$ led to the complete disappearance of the intermediates $4 \mathbf{a}$ and $5 \mathbf{a}$ and afforded $\mathbf{6 a}$ as a single product in $60 \%$ isolated yield (Table 1, entry 9). The role of intermediates $4 \mathbf{a}$ and 5a in the formation of $\mathbf{6 a}$ was further substantiated by treating $4 \mathbf{a}$ with $\mathrm{NaN}_{3}$ in DMF at $120^{\circ} \mathrm{C}$ and by heating $5 \mathbf{a}$ in DMF at $120^{\circ} \mathrm{C}$. As envisaged, both reactions furnished $\mathbf{6 a}$ as a single product in $87 \%$ and $90 \%$ isolated yield, respectively (Scheme 2). Replacing DMF with yet another polar aprotic solvent, i.e., DMSO, produced similar results except for a marginal increase in the isolated yield of $6 \mathbf{a}$ to $64 \%$ in $15 \mathrm{~h}$ (Table 1 , entries 10-13).

\section{$4 a$

$\mathrm{NaN}_{3}(3)$ in DMF \\ $120^{\circ} \mathrm{C}, 18 \mathrm{~h}$ \\ (Isolated yield 87\%)

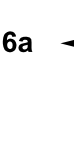

Scheme 2: Transformation of intermediates $4 \mathbf{a}$ and $5 \mathbf{a}$ to $\mathbf{6 a}$.

Next, in order to reduce the reaction times and to enhance the isolated yield of the annulated product $\mathbf{6 a}$, we applied microwave conditions instead of conventional heating and monitored the progress of the reaction at different time intervals. A significant increase in the yield of $\mathbf{6 a}$ resulting from the increase in the reaction times under microwave conditions was observed. Initially, a $10 \mathrm{~min}$ irradiation of the reaction mixture furnished the intermediate $4 \mathbf{a}$ as the only product in $80 \%$ isolated yield (Table 1, entry 14), whereas a 30 min irradiation resulted in a mixture of $\mathbf{4 a} / \mathbf{5 a} / \mathbf{6} \mathbf{a}$ in $20 / 45 / 10 \%$ yields as evident from HPLC (Table 1, entry 15). Extending exposure to microwave conditions for $1 \mathrm{~h}$ produced a mixture of $\mathbf{5 a}$ and $\mathbf{6 a}$ (Table 1, entry 16); however, a further exposure up to $1.5 \mathrm{~h}$ furnished the desired compound $\mathbf{6 a}$ as the only product in $71 \%$ isolated yield (Table 1, entry 17). Thus, under microwave irradiation conditions, not only the isolated yield of $\mathbf{6 a}$ increased from $60 \%$ under conventional heating to $71 \%$, but the duration of reaction was also reduced from $15 \mathrm{~h}$ to $1.5 \mathrm{~h}$. Switching the solvent from DMSO to DMF under microwave conditions furnished 6a in slightly reduced yield (Table 1, entry 18) while the use of $\mathrm{CH}_{3} \mathrm{CN}$ and $\mathrm{CH}_{3} \mathrm{OH}$ failed to produce the desired product (Table 1, entry 19 and 20). Replacing $\mathrm{Cs}_{2} \mathrm{CO}_{3}$ with other bases such as $\mathrm{K}_{2} \mathrm{CO}_{3}, \mathrm{Na}_{2} \mathrm{CO}_{3}, \mathrm{~K}_{3} \mathrm{PO}_{4}, t$-BuOK, DBU and TEA either produced a mixture of $5 \mathbf{a} / \mathbf{6 a}$ or furnished $6 \mathbf{a}$ in reduced yields (Table 1, entries 21-26). The observations clearly suggest that the formation of $\mathbf{6} \mathbf{a}$ in the three-component format involved intermolecular $N-1$ alkylation of the 2-alkynylindole 1a with epichlorohydrin to form $\mathbf{4 a}$, ring opening of $\mathbf{4 a}$ with sodium azide to form $\mathbf{5 a}$, and finally an intramolecular Huisgen azide-internal alkyne 1,3-dipolar cycloaddition reaction.

Once the reaction conditions for the three-component format had been optimized, several 2-alkynylindoles bearing different functional groups were treated with epichlorohydrin and sodium azide in order to establish the scope and limitation of the strategy. In total 22 compounds $\mathbf{6 a}-\mathbf{v}$ (Scheme 3) were synthesized, with their isolated yields varying from $54-73 \%$. The findings suggest that although the electronic properties of the substitution $\left(\mathrm{R}^{1}\right)$ on the phenyl ring of the indole had no effect on the outcome of the isolated yield of the final products, the nature of $\mathrm{R}^{2}$ had a profound effect on the yields. When the aromatic group was used as $\mathrm{R}^{2}$, the final products $6 \mathbf{a}-\mathbf{c}$ and 6e- $\mathbf{q}$ were obtained in isolated yields ranging from $66-73 \%$, whereas substituting $\mathrm{R}^{2}$ with aliphatic/trimethylsilyl moieties furnished the cyclized products $(\mathbf{6} \mathbf{d}$ and $\mathbf{6 r}-\mathbf{v})$ in diminished $(54-65 \%)$ isolated yields.

\section{Conclusion}

In conclusion, we have developed a simple and efficient threecomponent domino reaction for the synthesis of highly substituted indolodiazepinotriazoles in good yields under microwave conditions. The domino sequence comprising $N-1$ alkylation, ring opening of the epoxide, and intramolecular Huisgen azide-internal alkyne 1,3-dipolar cycloaddition reaction, led to the generation of the diazepine and triazole rings annulated to the indole through the formation of four new sigma bonds in a single step. 

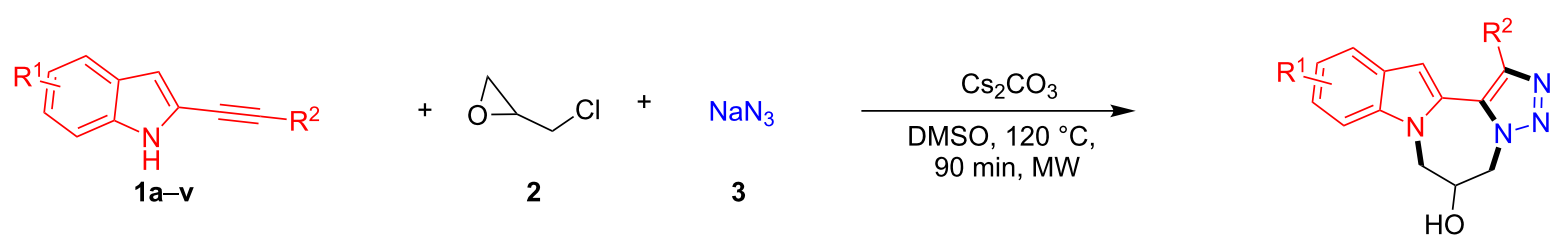

$6 a-v$ $54-73 \%$ yield

$\mathrm{R}^{2}=\mathrm{Ph}, 4-\mathrm{Me} \mathrm{Ph}, 4-t-\mathrm{BuPh}, \mathrm{C}_{6} \mathrm{H}_{9}, n-\mathrm{Bu}, n-\mathrm{Hex}, \mathrm{C}_{3} \mathrm{H}_{9} \mathrm{Si}$<smiles>Cc1ccc(-c2nnn3c2-c2cc4ccccc4n2CC(O)C3)cc1</smiles>

6a, $71 \%$<smiles>OC1Cn2nnc(-c3ccccc3)c2-c2cc3ccccc3n2C1</smiles>

6b, $68 \%$<smiles>COc1cc2cc3n(c2cc1OC)CC(O)Cn1nnc(-c2ccccc2)c1-3</smiles>

6f, $70 \%$<smiles>OC1Cn2nnc(-c3ccc([13C](=[Te])c4ccccc4)cc3)c2-c2cc3cc4c(cc3n2C1)OCO4</smiles>

$6 k, 66 \%$<smiles>Cc1ccc(-c2nnn3c2-c2cc4cc(Cl)ccc4n2CC(O)C3)cc1</smiles>

$6 p, 71 \%$<smiles>OC1Cn2nncc2-c2cc3ccccc3n2C1</smiles>

$6 u, 57 \%$<smiles>COc1cc2cc3n(c2cc1OC)CC(O)Cn1nnc(-c2ccc(C)cc2)c1-3</smiles>

$6 \mathbf{g}, 69 \%{ }^{\mathrm{OH}}$<smiles>COc1ccc(-c2nnn3c2-c2cc4cc5c(cc4n2CC(O)C3)OCO5)cc1</smiles>

6I, $69 \%$<smiles>CC(C)(C)c1ccc(-c2nnn3c2-c2cc4ccccc4n2CC(O)C3)cc1</smiles>

6c, $73 \%$<smiles>COc1cc2cc3n(c2cc1OC)CC(O)Cn1nnc(-c2ccc([13CH2])cc2)c1-3</smiles>

6h, $71 \%$ OH<smiles>COc1cccc2cc3n(c12)CC(O)Cn1nnc(-c2ccccc2)c1-3</smiles>

$6 \mathrm{~m}, 67 \%$<smiles>OC1Cn2nnc(C3=CCCCC3)c2-c2cc3ccccc3n2C1</smiles>

6d, $65 \%$<smiles>COc1ccc(-c2nnn3c2-c2cc4ccccc4n2CC(O)C3)cc1</smiles>

6e, $66 \%$<smiles>OC1Cn2nnc(-c3ccccc3)c2-c2cc3cc4c(cc3n2C1)OCO4</smiles>

6i, $67 \%$<smiles>COc1cccc2cc3n(c12)CC(O)Cn1nnc(-c2ccc(C)cc2)c1-3</smiles>

6n, $71 \%$<smiles>Cc1ccc(-c2nnn3c2-c2cc4cc5c(cc4n2CC(O)C3)OCO5)cc1</smiles>

$6 \mathbf{j}, 68 \%$<smiles>COc1cccc2cc3n(c12)CC(O)Cn1nnc(-c2ccc(C(C)(C)C)cc2)c1-3</smiles>

6o, $70 \%$<smiles>OC1Cn2nnc(-c3ccccc3)c2-c2cc3cc(Cl)ccc3n2C1</smiles><smiles>OC1Cn2nnc(Br)c2-c2cc3ccccc3n2C1</smiles><smiles>OC1Cn2nnc(Br)c2-c2cc3cc4c(cc3n2C1)OCO4</smiles><smiles>Oc1nnn2c1-c1cc3cc4c(cc3n1CC(O)C2)OCO4</smiles>

$6 q, 72 \%$

$6 r, 63 \%$

6s, $61 \%$

6t, $63 \%$ 


\section{Supporting Information}

\section{Supporting Information File 1}

Experimental section, copies of ${ }^{1} \mathrm{H},{ }^{13} \mathrm{C}$ NMR and HRMS spectra of starting and final compounds $\mathbf{1 e}, \mathbf{1} \mathbf{h}, \mathbf{1} \mathbf{j}-\mathbf{1}$,

1n-1t, 1v, 4a, 5a and 6a-6v.

[http://www.beilstein-journals.org/bjoc/content/

supplementary/1860-5397-9-41-S1.pdf]

\section{Acknowledgements}

RKA and SKS are thankful to CSIR, New Delhi, India for financial support. CDRI Communication No. 8380.

\section{References}

1. Rostovtsev, V. V.; Green, L. G.; Fokin, V. V.; Sharpless, K. B. Angew. Chem., Int. Ed. 2002, 41, 2596.

doi:10.1002/1521-3773(20020715)41:14<2596::AID-ANIE2596>3.0.CO ;2-4

2. Prescher, J. A.; Bertozzi, C. R. Nat. Chem. Biol. 2005, 1, 13. doi:10.1038/nchembio0605-13

3. Miaoa, T.; Wang, L. Synthesis 2008, 363. doi:10.1055/s-2008-1032037

4. Wangler, C.; Schirrmacher, R.; Bartenstein, P.; Wangler, B. Curr. Med. Chem. 2010, 17, 1092. doi:10.2174/092986710790820615

5. Walsh, J. C.; Kolb, H. C. Chimia 2010, 64, 29. doi:10.2533/chimia.2010.29

6. Lal, S.; Díez-González, S. J. Org. Chem. 2011, 76, 2367. doi:10.1021/jo200085j

7. Saha, B.; Sharma, S.; Sawant, D.; Kundu, B. Synlett 2007, 1591. doi:10.1055/s-2007-982543

8. Li, P.; Wang, L. Lett. Org. Chem. 2007, 4, 23. doi:10.2174/157017807780037513

9. Kumar, I.; Rode, C. V. Chem. Lett. 2007, 36, 592. doi:10.1246/cl.2007.592

10. Liu, M.; Reiser, O. Org. Lett. 2011, 13, 1102. doi:10.1021/ol103134c

11. Zhang, L.; Chen, X.; Xue, P.; Sun, H. H. Y.; Williams, I. D.; Sharpless, K. B.; Fokin, V. V.; Jia, G. J. Am. Chem. Soc. 2005, 127, 15998. doi:10.1021/ja054114s

12. Yoo, E. J.; Ahlquist, M.; Bae, I.; Sharpless, K. B.; Fokin, V. V.; Chang, S. J. Org. Chem. 2008, 73, 5520. doi:10.1021/j0800733p

13. Meldal, M.; Tornøe, C. W. Chem. Rev. 2008, 108, 2952. doi:10.1021/cr0783479

14. Sau, M.; Rodríguez-Escrich, C.; Pericàs, M. A. Org. Lett. 2011, 13, 5044. doi:10.1021/ol201869y

15. Kwok, S. W.; Fotsing, J. R.; Fraser, R. J.; Rodionov, O. V.; Fokin, V. V. Org. Lett. 2010, 12, 4217. doi:10.1021/ol101568d

16. Becer, C. R.; Hoogenboom, R.; Schubert, U. S. Angew. Chem., Int. Ed. 2009, 48, 4900. doi:10.1002/anie.200900755

17. Agalave, S. G.; Maujan, S. R.; Pore, V. S. Chem.-Asian J. 2011, 6, 2696. doi:10.1002/asia.201100432

18. Qin, A.; Lam, J. W. Y.; Tang, B. Z. Chem. Soc. Rev. 2010, 39, 2522. doi:10.1039/b909064a

19. Mandadapu, A. K.; Sharma, S. K.; Gupta, S.; Krishna, D. G. V.; Kundu, B. Org. Lett. 2011, 13, 3162. doi:10.1021/ol201092k

20. Aizpurua, J. M.; Azcune, I.; Fratila, R. M.; Balentova, E.; Sagartzazu-Aizpurua, M.; Miranda, J. I. Org. Lett. 2010, 12, 1584. doi:10.1021/ol1003127
21. Fiandanese, V.; Bottalico, D.; Marchese, G.; Punzi, A.; Quarta, M. R.; Fittipaldi, M. Synthesis 2009, 3853. doi:10.1055/s-0029-1217017

22. Arigela, R. K.; Mandadapu, A. K.; Sharma, S. K.; Kumar, B.; Kundu, B. Org. Lett. 2012, 14, 1804. doi:10.1021/ol300399y

23. Guggenheim, K. G.; Toru, H.; Kurth, M. J. Org. Lett. 2012, 14, 3732. doi:10.1021/ol301592z

24. Kunick, C. Liebigs Ann. Chem. 1993, 1141. doi:10.1002/jlac.1993199301182

25. Akritopoulou-Zanze, I.; Gracias, V.; Djuric, S. W. Tetrahedron Lett. 2004, 45, 8439. doi:10.1016/j.tetlet.2004.09.117

26. Oliva, A. I.; Christmann, U.; Font, D.; Cuevas, F.; Ballester, P.; Buschmann, H.; Torrens, A.; Yenes, S.; Pericàs, M. A. Org. Lett. 2008, 10, 1617. doi:10.1021/ol800291t

27. Majumdar, K. C.; Ray, K.; Ganai, S. Synthesis 2010, 2101. doi:10.1055/s-0029-1218763

28. Donald, J. R.; Martin, S. F. Org. Lett. 2011, 13, 852. doi:10.1021/ol1028404

29. Conrad, W. E.; Rodriguez, K. X.; Nguyen, H. H.; Fettinger, J. C.; Haddadin, M. J.; Kurth, M. J. Org. Lett. 2012, 14, 3870. doi:10.1021/ol3015804

30. Gracias, V.; Darczak, D.; Gasiecki, A. F.; Djuric, S. W. Tetrahedron Lett. 2005, 46, 9053. doi:10.1016/j.tetlet.2005.10.090

31. Sharma, S. K.; Mandadapu, A. K.; Saifuddin, M.; Gupta, S.; Agarwal, P. K.; Mandwal, A. K.; Gauniyal, H. M.; Kundu, B. Tetrahedron Lett. 2010, 51, 6022. doi:10.1016/j.tetlet.2010.09.054

32. Sharma, S. K.; Gupta, S.; Saifuddin, M.; Mandadapu, A. K.; Agarwal, P. K.; Gauniyal, H. M.; Kundu, B. Tetrahedron Lett. 2011, 52, 65. doi:10.1016/j.tetlet.2010.10.147

33. Gupta, S.; Kumar, B.; Kundu, B. J. Org. Chem. 2011, 76, 10154. doi:10.1021/jo201994v

34. Gupta, S.; Sharma, S. K.; Mandadapu, A. K.; Gauniyal, H. M.; Kundu, B. Tetrahedron Lett. 2011, 52, 4288. doi:10.1016/j.tetlet.2011.06.021

35. Sharma, S. K.; Mandadapu, A. K.; Kumar, B.; Kundu, B. J. Org. Chem. 2011, 76, 6798. doi:10.1021/jo201228t

36. Nagamochi, M.; Fang, Y.-Q.; Lautens, M. Org. Lett. 2007, 9, 2955. doi:10.1021/ol071370w

37. Fiandanese, V.; Bottalico, D.; Marchese, G.; Punzi, A. Tetrahedron 2008, 64, 7301. doi:10.1016/j.tet.2008.05.059

\section{License and Terms}

This is an Open Access article under the terms of the Creative Commons Attribution License (http://creativecommons.org/licenses/by/2.0), which permits unrestricted use, distribution, and reproduction in any medium, provided the original work is properly cited.

The license is subject to the Beilstein Journal of Organic Chemistry terms and conditions: (http://www.beilstein-journals.org/bjoc)

The definitive version of this article is the electronic one which can be found at: doi: $10.3762 /$ bjoc 9.41 